\title{
Determining the Wage Rate in Islamic Leasing Scheme of Selected Malaysian Financial Institution: A Requirement in Developing the Economy of Society
}

\author{
Anisah Nasib ${ }^{1}$, Siti Nadiah Mohd Salim² and Muhammad Solihin Yaakub ${ }^{3}$ \\ \{anisah_nasib.poli@1govuc.edu.my,nadiah_salim.poli@1govuc.edu.my,solihin.poli@1govuc.edu.my\} \\ ${ }^{123}$ Jabatan Pengajian Am, Politeknik Sultan Azlan Shah, Behrang Stesen, 35950 Behrang, Perak, \\ Malaysia
}

\begin{abstract}
This study aims to investigate the determination of wage rate in Islamic leasing scheme of selected Malaysian Financial Institution in developing the economy of Muslims. This is a qualitative study which utilises three data methods of data collection namely observation, interview and documental evidences. The data has been descriptively analysed. The findings of the study proved that majority of the Islamic pawn centre in Malaysia used three main instruments, particularly, ar-rahnu, al-qard and al-wadi'ah yad dhamanah. Thus, the wage rate for keeping the goods is based on the principle of al-wadi'ah yad dhamanah. However, the rate varied between institutions. Findings of the study revealed that the collection of wage rate can be implemented provided that the rate did not exceed one percent of every RM 100 of the marhun value. As a conclusion, the Islamic leasing or pawn services in Malaysia has significantly assisted in developing economy of Malaysian society and has been getting supports from Muslims as well as non-Muslims due to the reasonable wage rate. Among the implications of this research was the involved authority need to create special Act relating to Islamic leasing scheme because to dateis only based on the guidelines of Islamic Leasing Activities (Ar-Rahnu) issued by the Malaysian Co-operative Commission (SKM).
\end{abstract}

Keywords: Wage Rate, Islamic Pawn, Selected Financial Institution

\section{Introduction}

The practice of leasing has already existed since the Jahiliyyah period. During that time, among the Arab community, a leased item will be the property of the mortgage holder if the financier is unable to settle his/ her debts within the appointed time (Jawad 'Ali, 1971). The practice of leasing is recognized after the advent of Islam as one of the approach of aggrement or pleadge for repayment of debt by the financier. Prophet Muhammad (pbuh) once pawned his suit of armour as a mortgage and this proved that the practice has been taught since early Islamic era. As what has been mentioned in the hadith:

$$
\text { عن عائشة رضي الله عنها: أَ النبي لـنرى من يهودي طعاما إلى أجل ور هنه در عه من حديد }
$$

Translation: "From Aisyah r.a, said that Prophet Muhammad (pbuh) bought food from a Jewish by leasing his suit of armour as a form of leasing" 
Based on the hadith, it is proven that the prophet has been very moderate in his life. In a normal basis, he did not store food for himself and the family. Therefore, there were times when he had to lease his suit of armour to a Jewish to buy food despite its being an asset for him to fight in wars and to protect him from the enemy's weapons (Al-Bukhari, 1981).

Islam categorised leasing (ar-rahnu) as harus (necessity) as one of the method of settling financial burdens. The practice of borrowing money in the form of property (ar-rahnu) is one of the syara' compliance approach as mentioned by Allah SWT in al-Quran:

(Surah Al-Baqarah: Ayah 283)

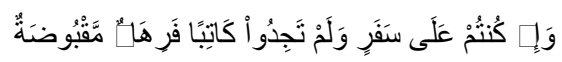

Translation: "And if you are on a journey and cannot find a scribe, pledges [may be taken] in hand: but if you trust one another, then let him who is trusted fulfil his trust, and let him be conscious of God, his Sustainer."

Based on the ayah, Allah SWT stressed that all lending and borrowing business required a witness and a written record in any circumstances except for during emergency. During travels, a borrower should hand over an item as a collateral of his debts (Salahuddin Abdullah, 2009).

The Islamic mortgage scheme has been introduced in Malaysia since 1992 as an alternative to the conventional mortgage scheme that has been in existence for so long. The use of conventional mortgage system is banned in Islam because there is an element of riba in its transaction, thereby suppressing the poor and the poor who make the mortgage contract. This is because, based on the Pawnbrokers Act 1972 (the conventional charge act) two percent interest per month can be charged on granted loans (Pawnbrokers (Amendment) Regulations, 1982).

After the introduction of Islamic pawnshops in Malaysia, the Islamic community has shifted from conventional systems towards a more secure and profitable Islamic system of both contracting parties. Majority of Islamic mortgage institutions in the country only charge wages on low cost mortgages. However, there is also an Islamic pawnbroking institution that does not charge any fees or charges to the mortgagor that is Terengganu Islamic Muassasah Mortgage (Shamsiah, 2008).

The basis of wage collection on mortgage charged on the leaser conforms to the Islamic law. In addition, lower wage rates help reduce the burden of financiers. The scheme has also received positive response among the community. In relation to that, several financial institutions and banks have applied Islamic pawn scheme as one of their institution's products such as Bank Rakyat Islamic Mortgage, Malaysia Islamic Economic Development Foundation (YaPEIM), Bank Islam, Agro Bank and the latest, Pos Malaysia.

\section{Problem Statement}

$\mathrm{n}$ Malaysia, the Islamic pawnbroking system was pioneered by Terengganu State Government which officially launched the Terengganu Islamic Muassasah Mortgage (TIMM) on 23 January 1992 which is based on ar-rahnu and al-qard al-hasan (Azila Abdul Razak, 2011). Furthermore, Permodalan Kelantan Berhad set up the Ar-Rahnu Shop introducing the concept of wages in Islamic pawnshops on 12 March 1992. On October 27, 1993, Bank Rakyat in collaboration with Malaysia Islamic Economic Development Foundation (YaPEIM) 
also introduced a scheme of Islamic pawnbroking which also charge wages (Azizah Othman, Norashidah Hashim and Syahrina Abdullah, 2012).

Wages charged based on leased items are counted as wadi'ah as clearly stated in the pamphlet of Islamic pawnshops by those institutions. This scheme is based on three main principles namely al-qard al-hasan, ar-rahnu and al-wadi'ah yad dhamanah. The problem arises is what factors are considered in determining the rate of wages in Islamic mortgage schemes in Malaysian Islamic pawnbroking institutions is this scheme a necessity in developing the Malaysian economy? As such, the focus of this study is on the setting of the wage rate in the Islamic mortgage scheme at selected financial institutions in Malaysia and the need to develop the economy of Malaysian society.

The research questions are:

a) How is the setting of a wage rate determined in Islamic pawnshops scheme among selected financial institutions in Malaysia?

b) Is the Islamic pawnshops scheme necessary in developing the economy of Malaysian society?

The research objectives are:

a) To analyze the setting of wage rates in Islamic pawnshops scheme at selected financial institutions in Malaysia.

b) To identify the necessity of Islamic pawnshops scheme in building a community economy

\section{Literature Review}

Based on the research title; " Determining the Wage Rate in Islamic Leasing Scheme of Selected Malaysian Financial Institution: A Requirement in Developing the Economy of Society ", researchers have made a survey of Islamic Mortgage Scheme (ar-rahnu). Islamic pawnshops or ar-rahnu intended to make an item or property as collateral for borrowed debts (Mustofa Al-Khin, 2005). If the debt can not be settled, the collateral can be used as payment to the debtor's debt (Abdullah Alwi Hj Hassan, 2007). This is an allowed practice in the Islamic law as one of the requirement of the Islamic sale and purchase.

In Malaysia, Islamic pawnshops were introduced in 1992 as an alternative to conventional mortgage systems. The Islamic community has increasingly receiving this scheme year after year as it is much better than conventional pawnshops (Nur Hayati Rasmin \& Ruzian Markom, 2014). In addition, this scheme is a financial instrument that provides convenience and assistance to the public to get cash loans easily and quickly based on Islamic law. It is also one of the safer and more profitable financial contracts for both contracted parties (Abdul Halim El-Muhammady, 2012).

Islamic pawnshops are more profitable to borrowers as most Islamic pawnshops in the country only charge a fee for storing goods. There is also an Islamic pawnbroker institution that does not charge any fees or charges ie Terengganu Islamic Muassasah Mortgage (S.Hisham et al, 2013). Customers are particularly interested to use this scheme as it only charges a low wage rate. Islamic pawnshops can not charge wages over one percent of the marhun value as compared to conventional pawnshops that charge two percent of the value of the loan (Shamsiah Mohamad, 2008; Pawnbrokers (Amendment) Rules, 1982).

In addition, these financial instruments are not only accepted in this country, but other countries have also adopted the implementation as mentioned by Sapeing Masae (2011) and 
Akhmad Hanafi Dain Yunta (2007) study. Both studies, were carried out in Thailand and South Sulawesi. Sapaeing Masae explains that there are three forms of mortgage practiced in Pattani, Thailand, the traditional pawnshops, conventional pawnshops and Islamic pawnshops. Based on the three forms of charge, the Islamic mortgage system is gaining public response because it does not involve riba' and fraud in its transaction. Similarly, in the study of Akhmad Hanafi Dain Yunta stated that people are increasingly adopting Islamic pawnshops scheme compared to conventional pawnshops despite the debate on the legal point of use of mortgage property.

\section{Research Methodology}

In general, this study was conducted using descriptive qualitative methods. Qualitative methods are defined as studies that do not involve measurements or statistical techniques as well as investigations through statistical procedures (Strauss, A. \& Corbin, J., 1990). Qualitative research can be referred to as a research approach that emphasizes descriptive, inductive, basic theoretical constructs and studies on how humans provide meaning to their lives (Rozmi Ismail, 2013). This study was conducted using the method of observation, interview, descriptive and evidential in data collection. The overview of the use of these methods will be as follows:

\subsection{Method of Observation}

Observation is an effective technique used in data collection to study and understand the processes that occur in the study. In this method researchers will see, hear, observe and ask to understand what is happening in realistic situations and circumstances. Researchers will engage in a way that does not interfere with the research process. The method of data collection used based on this method is the form of participative observation (Sabitha Marican, 2009).

\subsection{Method of Interview}

Interview is a method that will be used in this study which involves the interview between the researcher and the subject of the interview to obtain relevant information with the study. Through this interview method, data obtained from observations can be strengthened and complemented. This means that it is a triangulation intended to verify the data or information obtained. The interview method used was based on unstructured interviews (Rozmi Ismail, 2013).

\subsection{Method of Evidential Document}

In addition to observation and interview techniques, evidential document will also be used in this study. This method involves the analysis of data obtained from the documents used by researchers to see the forms, patterns and trends that occur and provide solid evidence to strengthen the credibility of interview techniques and observations. The technique of collecting and gathering information from this document also gives researchers the opportunity to add, compare and reinforce the study data (Sabitha Marican, 2009). 


\subsection{The Need Of Islamic Leasing Scheme In The Developing The Economy Of Malaysian Society}

The need for Islamic pawnshops is one of the important instruments in developing the society economy, especially the local community. This can be seen from three aspects, namely, the source of capital to entrepreneurs of Small and Medium Enterprises (SME), financing education loans and community services (Mohd Ali, 2005). These three aspects will clearly explain how Islamic pawnshops can develop the Malaysian economy.

\subsubsection{The source of Capital to Entrepreneurs of Small and Medium Enterprises (SME)}

According to the Small and Medium Enterprise Corporation (SME Corp. Malaysia), a new definition of SMEs covering all sectors of service has been established which covers manufacturing, agriculture, construction as well as mining and quarrying. The two main criteria for determining the scale of the enterprise are the annual sales volume and the full number of employees. SMEs for the manufacturing sector are defined as firms with annual sales of not more than RM50 million or not more than 200 full-time employees. Meanwhile, SMEs for the services sector and other sectors are defined as firms with annual sales of not more than RM20 million or not more than 75 full-time employees.

In Malaysia, there are various SME venture opportunities that receive full support from the government. The Government offers various forms of financing assistance to SME entrepreneurs. This assistance is channeled through responsible agencies as well as through financial institutions. SMEs often faced difficulties in getting capital loans from financial institutions. This is because of the small and limited production of SMEs, no collateral or appropriate guarantor and lack of business record due to poor management system that resulted their application to be rejected (Moha Asri, 1999). Additionally, financial institutions are unsure about the ability of SMEs to repay loans within the specified timeframe. Most of SME's capital resources are from the savings of its own entrepreneurs as well as donations or loans from relatives and friends.

Therefore, Islamic pawnshops provide financial aid to facilitate capital investments as well as the rollings of capital. For example, Ar-Rahnu YaPEIM provides easy, fast and secure micro-credit facilities to the public especially those with low income for small-business capital and other productive activities. This can help the country in developing the socio-economic status of the populations and successfully attracting SME entrepreneurs to opt for Islamic pawnshops as their business capital source. There is a study found that many, especially Kelantanese female SME entrepreneurs choose this Islamic pawn scheme as they need fast money as capital, purchase stocks and so on (Azizah Othman et al, 2012).

\subsubsection{Financing Education Loans}

Education is the key asset of the country's development. Neglecting the importance of education is to hinder the achievement of the nation and to limit individual needs both for personal and social purposes. The importance of this education can be seen clearly when there is a high allocation of expenditure in the education sector and government daring actions of risk taking to produce competitive human capital in the future.

In the 2018 Touchpoints Budget presentation by the Prime Minister cum Minister of Finance, YAB Dato 'Sri Mohd Najib Tun Haji Abdul Razak on 27th October 2017, Education became the Third Thrust to top the development of education, training and skills as well as talents. Government has also allocated RM45.9 billion to the Ministry of Education for 
managing and developing expenditure including providing schooling assistance to over 5.2 million students nationwide. This huge allocation demonstrates the government's seriousness and emphasis on education as one of the key elements of national progress and development.

Hence, without education, our society will be backward and left behind in the rapid development of modernization which is being carried out in foreign countries. The rising cost of living not only affects the lower income group, but also the middle-income group that is the majority in Malaysia. This includes costs incurred in the education sector such as the cost of school supplies, fees, housing rental and so on.

Thus, Islamic pawnshops can overcome the problems of the needy by using these facilities such as financing home as well as emergency and education needs (Abdul Ghafar and Nor Zakiah, 1997). The Islamic pawnshops scheme does not require reasons for leasing compared to application of loans from financial institution, which requires more stringent information such as income statement projections (for business purposes) as well as guarantors. In contrast to Islamic pawnshops, it does not impose restrictions or provisions on the way in which the funds will be used. Furthermore, the process is fast and easy which takes less than 30 minutes. (Calvin W. H. Cheong et al, 2012).

Hence, the financial loans provided by Islamic pawnbroking institutions can provide a bit of help to students who need immediate educational funds. Apart from the fast and easy and process, the cost of wages is also reasonable. Hence, the country's aspiration to produce intelligent, progressive workforce with high level of integrity will be possible because of these financial facilities.

\subsubsection{Significance in the Community Service}

Various efforts have been made to help low-income people to develop their lives in Malaysia. Those in need of financial assistance will go to financial institutions to apply for loans but are bound by stringent rules and regulations for obtaining loans. This requirement can be overcome with micro credit scheme whereby Islamic pawnshops scheme is regarded as the best alternative to solve the situations.

Islamic pawnbroking customers are classified into three categories: housewives, private workers and civil servants (Azizah Othman, 2015). These groups tend to choose Islamic pawnshops as sources for obtaining financial loans because of their low income and inelligibility to apply for loans from banking institutions. Some also argue that Islamic pawnbroking customers include small businesses using these loans as source of business capital (Selamah et al, 2006).

There is also a study of non-Muslim communities in the country which states that Islamic pawnshops are totally different from conventional pawnshops based on their interest rates. They put in their jewellery at Islamic pawnbroking institutions for security guarantees, low wages and the features of the Islamic pawnshops (Nor Surilawana et al, 2014).

Islamic pawnshops in Malaysia are generally in the pursuit of social responsibility to the community, particularly in providing financial assistance with no burden on communities and by providing low service charges. This contrasts with the conventional pawnshops scheme which is more likely to put a burden on the lower income group which clearly is in contrast to the Islamic sharia practice (Azila Abdul Razak, 2004). 


\section{Result and Discussion}

Malaysian Islamic pawnbroking institutes are required to comply with GP25: Islamic Mortgage Tax Guidelines (Ar-Rahnu). Among the major requirements for the implementation of Islamic pawnshops in Malaysia is the adoption of some fiqh concepts in its scheme that is al-rahn, al-qard and al-wadi'ah yad dhamanah. Al-Rahnu refers to a valued item that is used as a back-up to debt (loan) or in other words as a security of debt and is payable thereby if the debtor's debt can not be settled. Al-Wadi'ah Yad Dhamah refers to the savings of valuables which are collaterated such as gold and every savings will be charged for wages. Whereas, alQard refers to a loan given on a certain percentage of the value of marhun and wages are not charged on the basis of the amount of loans issued (Shamsiah, 2008; Fatimah Murni Jusuh, 2003).

Based on GP25: Islamic Mortgage Tax Guidelines (Ar-Rahnu), the prescribed rate of pay for each Islamic mortgage institution in Malaysia shall not exceed one per cent of each RM100 value of marhun. Of three Islamic pawnbroking institutions are made in this study: Ar-Rahnu Pos Malaysia Berhad, Ar-Rahnu Islamic Economic Development Foundation Malaysia (YaPEIM) and Ar-Rahnu Agro Bank. These three institutions are found to comply with GP25: Islamic Mortgage Tax Guidelines (Ar-Rahnu). However, there are still some differences, such as the ratio of wage rates, maximum financing rates, and financing periods. Comparison is more obvious as in the table below (Nurwadia binti Mohd Yusop, 2017; Mohd Rozaidi Hamat, 2017; Mohd Rusdy bin Mohammad Afandi, 2017).

Table 1. The Differences in the Implementation of Islamic Mortgage Scheme between Pos Malaysia Institutions, YaPEIM and Agro Bank

\begin{tabular}{|c|c|c|c|}
\hline \multirow[b]{2}{*}{ Item } & \multicolumn{3}{|c|}{ Differences } \\
\hline & Pos Malaysia & Yapeim & Agro Bank \\
\hline $\begin{array}{l}\text { Wage Rate } \\
\text { / } 100 \text { value } \\
\text { of marhun }\end{array}$ & RM 0.85 & RM 0.80 & $\begin{array}{c}\text { RM } 100 \text { to RM 2000: } \\
\text { RM } 0.50 \\
\text { RM 2001 to RM 5000: } \\
\text { RM } 0.60 \\
\text { RM 5001 and above: } \\
\text { RM } 0.75\end{array}$ \\
\hline $\begin{array}{l}\text { Margin of } \\
\text { Loans }\end{array}$ & $\begin{array}{c}75 \% \text { of the value of } \\
\text { marhun }\end{array}$ & $\begin{array}{l}70 \% \text { of the } \\
\text { value of } \\
\text { marhun }\end{array}$ & $70 \%$ of the value of marhun \\
\hline $\begin{array}{l}\text { Maximum } \\
\text { Financing }\end{array}$ & RM 100,000.00 & $\begin{array}{c}\mathrm{RM} \\
75,000.00\end{array}$ & RM $150,000.00$ \\
\hline $\begin{array}{l}\text { Financing } \\
\text { Period }\end{array}$ & $\begin{array}{l}6 \text { months }+6 \\
\text { months }\end{array}$ & $\begin{array}{c}6 \text { months }+ \\
2 \text { months }+ \\
2 \text { months }\end{array}$ & 6 months +6 months \\
\hline
\end{tabular}

The above table shows that the lowest rates of savings between these three institutions are in Ar-Rahnu Agro Bank's scheme compared to Ar-Rahnu YaPEIM and Ar-Rahnu Pos Malaysia. On the other hand, Ar-Rahnu Pos Malaysia has the highest margin of 75\% and followed by Ar-Rahnu Agro Bank and Ar-Rahnu YaPEIM of 70\% for both.

Next, the highest possible aspect of financing is Ar-Rahnu Agro Bank, amounting to RM150,000.00 followed by Ar-Rahnu Pos Malaysia of RM100,000.00 and lastly 
RM75,000.00 which is in Ar-Rahnu YaPEIM. While in terms of financing periods, the lowest period of funding is in Ar-Rahnu YaPEIM and the longest period of financing is for 12 months, in Ar-Rahnu Pos Malaysia and Ar-Rahnu Agro Bank.

Table 2. The Differences of Wage Rate: Pos Malaysia Berhad, YaPEIM dan Agro Bank

\begin{tabular}{|c|c|c|c|}
\hline \multicolumn{4}{|c|}{$\begin{array}{l}\text { Situation: "A debtor wants to make a gold mortgage with the value of his mortgage } \\
\text { (value marhun) amounting to RM715 and he wants to only apply for a loan of } \mathbf{R M} \\
\mathbf{5 0 0} \text { the value of marhun. The debtor wants to lease the goods up to six months." }\end{array}$} \\
\hline \multirow[t]{2}{*}{ Institution } & \multicolumn{3}{|c|}{$\begin{array}{l}\text { Wage Rate } \\
=\text { Value Of Marhun X Rate/100 X Financing Period }\end{array}$} \\
\hline & Pos Malaysia & YaPEIM & Agro Bank \\
\hline Calculation & $\begin{array}{l}=\text { RM } 500 \times \text { RM } \\
0.85 / 100 \times 6 \\
=\text { RM } 25.50\end{array}$ & $\begin{array}{l}=\mathrm{RM} 500 \times \mathrm{RM} \\
0.80 / 100 \times 6 \\
=\mathrm{RM} 24.00\end{array}$ & $\begin{array}{l}=\mathrm{RM} 500 \times \mathrm{RM} \\
0.50 / 100 \times 6 \\
=\mathrm{RM} 15.00\end{array}$ \\
\hline
\end{tabular}

Based on the calculation of the wage rate in Table 2, there is a difference in wage rates in the three institutions should the debtor borrow a sum of only RM500 from the value of marhun. If it is only for six months, Ar-Rahnu Agro Bank charged the lowest wage rate of only RM15.00. The value varies by RM9.00 compared to the charges in Ar-Rahnu YaEPIM. While the highest wage rate is at Ar-Rahnu Pos Melaysia Berhad of RM25.50, varying from RM10.50 of wage rate at Ar-Rahnu Agro Bank. This rate of wages will also increase according to the increment of mortgage period.

Hence, this study found that the Islamic pawnshops had a huge impact on the development of Malaysian economy. Its fast and easy system can attract the public to choose this scheme as a source for immediate money recovery. Its sharia-compliant transactions also attracted the public to leave the conventional pawnshops scheme hesitation that has been in existence for so long without hesitation.

\section{Conclusion}

This study has found that the majority of Islamic pawnbroking institutions in Malaysia absolutely impose wage rates on mortgage items to customers. However, these rates vary according to the institution as described in the findings of the study. these different wage rates allow customers to have alternatives on choosing the insitutions to go to. However, this rate difference can also cause confusion and misunderstandings among the public. Hence, adjustments need to be made for the implementation of Islamic pawnshops scheme in Malaysian Islamic pawnbroking institutions.

In addition, the implementation of Islamic mortgage schemes in Malaysia is also based on GP25: Islamic Mortgage Tax Guidelines (Ar-Rahnu). To date, no special act has been adopted as in conventional pawnshops using the Pawnbrokers Act 1972. Hence, the authorities need to establish a special act to be applied accordingly in all Malaysian Islamic pawnbroking 
institutions. Each institution also needs to strengthen the services provided to its customers and to make continuous improvements to the services.

As a conclusion, the setting up of wages in Islamic pawnshops does not burden the needy society, but it will give many benefits to the community and further promote their economy. The public is easy to accept this scheme because of the fast and easy monetary process, instant loans and can prevent themselves from borrowing from unauthorized sources such as unlicensed money lenders. Based on these responsibilities, it is undeniable that Islamic pawnbroking institutions have had a huge impact on developing the community and contributed towards the country's economic growth.

\section{References}

[1] Abdullah Alwi Hj Hassan, 2007. Sales and Contracts in Early Islamic Commercial Law. The Other Press. Kuala Lumpur.

[2] Abdul Halim El-Muhammady, 2012. Undang-undang Muamalat dan Aplikasinya Kepada Produk-produk Perbankan Islam, Aras Mega Sdn Bhd. Selangor.

[3] Akhmad Hanafi Dain Yunta, 2007. Hukum Pemanfaatan Harta Gadaian (al-Marhun): Aplikasinya dalam Penggadaian Syariah di Makassar Sulawesi Selatan. Fakulti Pengajian Islam. Universiti Kebangsaan Malaysia.

[4] Abdul Ghafar Ismail \& Nor Zakiah Ahmad, 1997. Pawnshop as an instrument of microenterprise credit in Malaysia. International Journal of Social Economics, Vol. 24 Iss: 11 hlm. 1343-1352.

[5] Al-Bukhari, 1981. Sahih al-Bukhari. Dar al-Fikr. Beirut.

[6] Azila Abdul Razak, 2011. Economic and Religious Significance of the Islamic and Conventional Pawnbroking in Malaysia: Behavioural and Perception Analysis. Durham E-Thesis. United Kingdom.

[7] Azizah Othman, Norashidah Hashim and Syahrina Abdullah, 2013. Perkembangan Ar-Rahnu di Terengganu: Kajian Kes Terhadap Majlis Agama Islam dan Adat Melayu Terengganu (MAIDAM). Prosiding Perkam VIII, Jilid 2 (2013) 951-959.

[8] Azizah Othman, Norashidah Hashim \& Syahrina Abdullah, 2012. Customer Satisfaction Levels of Service Quality at Ar-Rahnu, Kelantan. 3 rd International Conference on Business and Economic Research (3 ${ }^{\text {rd }}$ ICBER 2012) Proceeding; ISBN: 978-967-5705-05-2.

[9] Azizah Othman, 2015. Pelaksanaan Al-Rahnu Di Institusi Perbankan Dan Bukan Perbankan Di Malaysia, Tesis Ijazah Doktor Falsafah. Universiti Sains Malaysia.

[10] Calvin Cheong \& Jothee Sinnakkannu, 2012. Ar-Rahnu: Opportunities and Challenges in Malaysia. Available at SSRN: https://ssrn.com/abstract $=2112809$ or http://dx.doi.org/10.2139/ssrn.2112809 [Dicapai pada 25 Februari 2018]

[11] Jawad 'Ali, 1971. Al-Mufassal fi Tarikh Al-'Arab Qabl Al-Islam. Dar al-Qalam li al-Malayin. Beirut.

[12] Moha Asri Hj. Abdullah, 1999. Industri Kecil di Malaysia: Pembangunan dan Masa Depan. Dewan Bahasa \& Pustaka. Kuala Lumpur.

[13] Mohd Ali, B, 2005. A New Era in Microfinance in Malaysia. Available from: http:// www.pptserach.net/tag/sr-Rahnu-a-new-era-in-microfinance-in-Malaysia. [Dicapai pada 25 Februari 2018]

[14] Mustafa Dakian, 2005. Sistem Kewangan Islam. Utusan Publications \& Distributors Sdn. Bhd. Kuala Lumpur.

[15] Mustofa al-Khin et al.; penterjemahan Solehan Ayub, 2004. Al-Fiqh al-Manhaj al-Syafi'i. Pustaka Salam Sdn. Bhd. Kuala Lumpur. 
[16] Nor Surilawana Hj. Sulaiman et al, 2014. The Comparison Between ar-Rahnu and Conventional Pawn broking. Global Business and Economics Research Journal, 3(5):57-65.

[17] Nur Hayati Rasmin \& Ruzian Markom, 2014. Ar-Rahnu Governance Laws in Malaysia: an Analysis in Banks and Non-Banks Financial Institutions. International Conference of Global Islamic Studies 2014. Bangi.

[18] Rozmi Ismail, 2013. Metodologi Penyelidikan: Teori dan Praktis. Penerbitan Universiti Kebangsaan Malaysia. Bangi.

[19] S. Hisham, S. Abdul Shukor, A.B Ummi Salwa and Kamarulzaman, 2013. The Concept and Challenges of Islamic Pawn Broking (Ar-Rahnu). Middle-East Journal of Scientific Research 13 (Research in Contemporary Islamic Finance and Wealth Management): 98-102, 2013; ISSN 1990-9233.

[20] Sabitha Marican, 2009. Penyelidikan Sains Sosial; Pendekatan Pragmatik. Edusystem Sdn. Bhd. Batu Caves.

[21] Salahuddin Abdullah et al, 2009. Tafsir Mubin Juzuk 3. Perpustakaan Negara Malaysia. Kuala Lumpur.

[22] Sapaeing Masae, 2011. Amalan Pajak Gadai dalam Masyarakat Islam Pattani, Thailand Menurut Perspektif Islam. Kuala Lumpur: Jabatan Fiqh dan Usul, Akademi Pengajian Islam, Universiti Malaya.

[23] Selamah Maamor \& Abdul Ghafar Ismail, 2006. Micro-Credit Program: Pawnshop vs Ar-Rahn Working Paper in Islamic Economic and Finance No 0609 Presented at The Seminar Kebangsaan Pengurusan Harta Dalam Islam. Kolej Islam Pahang. Kuantan 8-9 August 2006.

[24] Shamsiah Mohamad, 2008. Upah Simpan Barang dalam Skim Ar-Rahnu: Satu Penilaian Semula, Jurnal Syariah Fiqh Vol. 5. Kuala Lumpur: Akademi Pengajian Islam, Universiti Malaya,

[25] Sheikh Abdullah Basmeih, 2007. Tafsir Ar-Rahman. Jabatan Kemajuan Islam Malaysia. Putrajaya.

[26] Strauss, A. \& Corbin, J, 1990. Basics of Qualitative Research: Graunded Theory Procedures and Techniques. CA: Sage Publications, Inc. Newbury Park.

[27] Temubual bersama Mohd Rozaidi Hamat (13 November 2017), Timbalan Pengurus Besar ArRahnu YaPEIM.

[28] Temubual bersama Mohd Rusdy bin Mohammad Afandi (23 Disember 2017), Kerani Pentadbiran Pembiayaan Agro Bank, Cawangan Tanjung Malim, Perak.

[29] Temubual bersama Nurwadia binti Mohd Yusop (23 Disember 2017), Pegawai Ar-Rahnu 1 @.POS, Cawangan Pos Malaysia Tanjung Malim, Perak.

[30] Akta Pemegang Pajak Gadai 1972.

[31] Pembentangan Bajet 2018 dibentangkan oleh YAB Dato' Sri Mohd Najib Bin Tun Abdul Razak, Perdana Menteri merangkap Menteri Kewangan pada 27 Oktober 2017 di Parlimen.

[32] Peraturan-peraturan Pemegang Pajak Gadai (Pindaan) 1982.

[33] Perbadanan Perusahaan Kecil dan Sederhana Malaysia (SME Corp. Malaysia). http:// www.smecorp.gov.my. 